\title{
Giant Gastrointestinal Stromal Tumor (GIST) of the Stomach and Huge Liver Metastase; Surgical Management
}

\author{
Aksoy $\mathrm{F}^{1}$, Yener $\mathrm{O}^{2 *}$ and Ekinci $\mathrm{O}^{2}$ \\ 'İstanbul Oncology Center, Turkey \\ ${ }^{2}$ İstanbul Göztepe Educational Hospital, Turkey \\ *Correspondling author: Oktay Yener, Plaj Yolu 35/6, \\ Caddebostan, İstanbul Göztepe Educational Hospital, \\ Turkey
}

Received: August 01, 2017; Accepted: October 16, 2017; Published: October 23, 2017

\section{Background}

Gastrointestinal Stromal Tumor's (GISTs) represent 85\% of all mesenchymal neoplasm's that affect the Gastro Intestinal (GI) tract. These GISTs range in size from small lesions to large masses. Often they are clinically silent until they reach a significant size, so their discovery is usually incidental. Gastrointestinal Stromal Tumor's (GISTs) are relatively common sub-epithelial tumors that occur most frequently in the stomach, small bowel, esophagus, and omentum. The liver is the most common metastatic site of a GIST $[1,2]$.

These tumors are located primarily in the stomach (60\% to $70 \%)$ and their discovery is often incidental. GISTs range in size from small lesions to large masses [3]. They are clinically silent until they reach a significant size; this is why their discovery is usually incidental. In many cases, GISTs present with abdominal pain, GI bleeding or palpable mass. We report an unusual case of a giant GIST that caused a huge liver metastases.

\section{Case Presentation}

This is a recent case of an exophytic GIST of gastric origin. A 53-year-old male presented with vague upper abdominal pain and feeling of an abdominal lump on and off for two years. There were no other associated general or GI tract symptoms. Clinical examination of the abdomen revealed a well-defined transversely mobile intraabdominal lump in the right hypochondrium of about $15 \times 8 \mathrm{~cm}$.

All routine blood test results and levels of tumor markers were within the normal ranges. Ultrasonography and computed tomography of the abdomen showed a large mass of $70^{\star} 35 \mathrm{~mm}$. Huge liver metastasis were seen in abdomen computed tomography (Figure $1)$.

The abdomen was explored electively and a $7 \times 4 \mathrm{~cm}$ tumor was seen arising from the greater curve of the stomach, exophytically, with a sessile base. There were huge liver metastases were seen in abdominal exploration (Figure 2). Partial gastrectomy was performed without any lymphadenectomy. Liver metastases were treated with imatinib therapy.

The patient was followed up with adjuvant therapy.
Histopathology of the tumor revealed a $7.5 \mathrm{~cm}$ sized neoplasm arising from the gastric sub-mucosa composed of fusiform and epitheloid cells. Mitosis was occasional at 5/50 Immunohistochemistry reported that the tumor cells were positive for C-KIT, CD 34, and S-100, Aktın, and Desmin were negative. The findings favored the diagnosis of epitheloid gastrointestinal Stromal tumor of high malignant potential. The respected margin was reported clear of the tumor.

\section{Discussion}

Gastrointestinal Stromal tumor can occur anywhere in the GI tract. They are sub-mucosal lesions frequently growing endophytically. They also manifest exophytically. Sizes of these tumors have been reported from small $1 \mathrm{~cm}$ to large $40 \mathrm{~cm}$ diameter excrescences [4]. About $50 \%$ to $75 \%$ of these originate in the stomach and about $20 \%$ in the small bowel, while less frequent sites include the colon and Rectum. Brunner's gland Hamartomas of the duodenum mimics the radiological and endoscopic features of GIST $[5,6]$.

In conclusion, large sized liver metastases are rare in the case of Gastrointestinal Stromal Tumor which generally present with varying duration of symptoms before surgery. These tumors may be difficult to distinguish from a number of other benign or malignant spindle cell lesions. Complete surgical resection of the tumor along with adjuvant therapy involving selective receptor tyrosine kinase

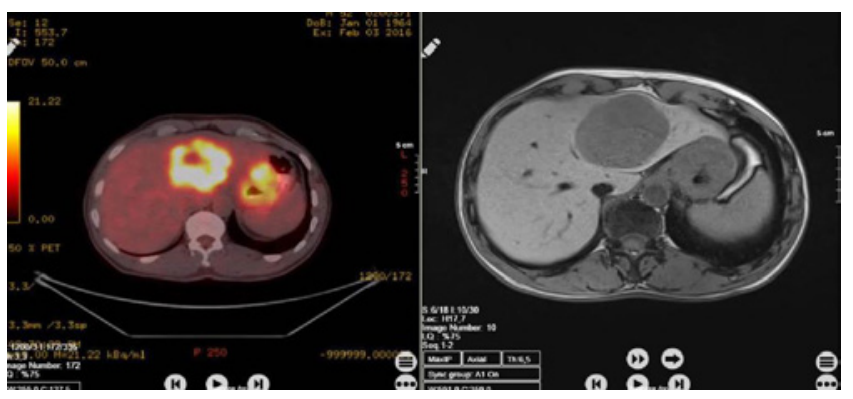

Figure 1: Large metastatic mass in the liver in CT findings.

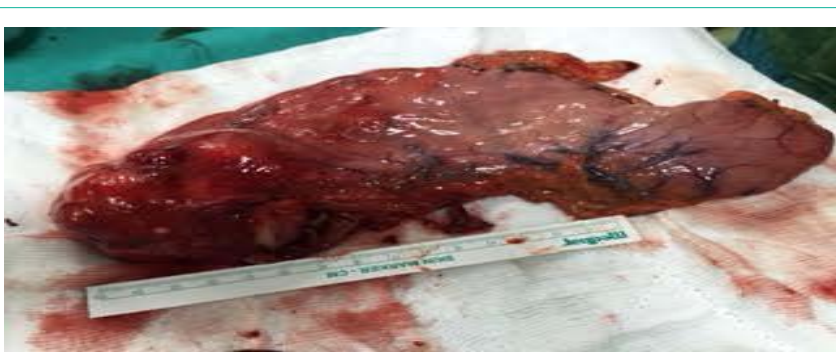

Figure 2: Respected specimen. 
inhibitors is effective, and should be considered as primary modalities of treatment in high-risk group GIST patients [6].

\section{References}

1. Osada T, Nagahara A, Kodani T, Namihisa A, Kawabe M, Yoshizawa T, et al. Gastrointestinal Stromal Tumor of the stomach with a giant abscess penetrating the gastric lumen. World J Gastroenterol. 2007; 28: 2385-2387.

2. Vij M, Agrawal V, Kumar A, Pandey R. Cytomorphology of Gastrointestinal Stromal Tumors and extra-Gastrointestinal Stromal Tumors: a comprehensive morphologic study. J Cytol. 2013; 30: 8-12.

3. Zhou L, Liu C, Bai JG, Wei JC, Qu K, Tian F, et al. A rare giant Gastrointestinal Stromal Tumor of the stomach traversing the upper abdomen: a case report and literature review. World J Surg Oncol. 2012; 10: 66
4. Fülöp E, Marcu S, Milutin D, Borda A. Gastrointestinal Stromal Tumors: review on morphology: diagnosis and management. Rom J Morphol Embryol. 2009; 50: 319-326.

5. Funahashi $\mathrm{H}$, Okada $\mathrm{Y}$, Sawai $\mathrm{H}$, Wakasugi $\mathrm{T}$, Akamo $\mathrm{Y}$, Manabe $\mathrm{T}$. Complete extra gastric growth in a giant Gastrointestinal Stromal Tumor: report of a case. Int Surg. 2008; 93: 45-49.

6. Morinaga N, Saito $\mathrm{H}$, Komine C, Matsumoto A, Katoh T, Tanaka N, et al. [Low-Dose and Interval Administration of Imatinib in a Patient with Liver Metastasis of the Gastrointestinal Stromal Tumor of the Stomach - A Case Report]. Gan to Kagaku Ryoho. 2017; 44: 161-164.
Austin J Surg - Volume 4 Issue 3 - 2017

ISSN : 2381-9030 | www.austinpublishing group.com

Yener et al. (C) All rights are reserved
Citation: Aksoy F, Yener O and Ekinci O. Giant Gastrointestinal Stromal Tumor (GIST) of the Stomach and Huge Liver Metastase; Surgical Management. Austin J Surg. 2017; 4(3): 1105. 